\title{
ЗАСОБИ ЕКСПРЕСИВНОГО СИНТАКСИСУ В ХУДОЖНЬОМУ ТЕКСТІ
}

Вавринюк Т. І. Засоби експресивного синтаксису в художньому тексті.

У статті йдеться про засоби експресивного синтаксису. Увагу звернено на звертання, номінативні речення, неповні та парцельовані структури. Обгрунтовано думку, що синтаксичні експресивні засоби не лише відзначаються художньозображальною місткістю, а й чуттєвої мають впливові якості.

Ключові слова: експресивний синтаксис, звертання, називний уявлення, номінативні речення, неповні речення, парцельовані структури.

Вавринюк Т. І. Средства экспрессивного синтаксиса в художественном тексте.

В статье рассматриваются средства экспрессивного синтаксиса. Внимание уделено обращению, номинативным предложениям, неполным и парцеллированным структурам. Обоснована мысль, что синтаксические экспрессивные средства не только отличаются художественно-изобразительной вместимостью, но также имеют влиятельные качества.

Ключевые слова: экспрессивный синтаксис, обращение, номинативные предложения, неполные предложения, парцеллированные структуры.

Vavrynyuk T. I. Facilities of expressive syntax in artistic text.

Speech goes in the article about facilities of expressive syntax. Paid attention to appeal, nominative constructions, incomplete. An idea is reasonable, that syntactic expressive facilities are not only marked an artistically-graphic capacity but also have influential internalss.

Key words: an expressive syntax, appeal, is nominative constructions, incomplete suggestions.

Сучасна стилістика актуалізує такі аспекти дослідження, які пов'язані з вивченням виражальних можливостей мовних одиниць. До найбільш активно досліджуваних лінгвістичних категорій належить експресивність, яка певним чином окреслює образ автора і водночас $\epsilon$ потужним засобом мовного впливу на читача.

Теорія експресивного синтаксису бере початок 3 60-х років минулого століття 3 праць Ш. Баллі й до нині активно розробляється такими вченими, як Р. Якобсон, В. Виноградов, О. Золотова, А. Загнітко, В. Чабаненко, О. Александрова, Е. Береговська, Е. Геллер та інші.

Як відзначають дослідники, спеціальне призначення експресивних побудов виявляється не тільки в тому, щоб передати адресату ту чи ту 
інформацію, а й привернути його увагу до неї, максимально акцентувати iii i таким чином посилити іiі дієвість. На думку Ш. Баллі, експресивний фактор є обов'язковим компонентом будь-якого висловлення [1, с. 20]: утілюючи думку в мовну форму, автор повідомлення неминуче передає $\mathrm{i}$ своє ставлення до того, про що йде мова. Отже, експресивність постає як феномен мовної особистості та ії суб’єктивних інтенцій. Таке розуміння експресивності ставить іiі в ряд 3 категорією суб'єктивної модальності (відношення мовця до того, про що він повідомляс): «Експресивність (від лат. expression - вираження) - сукупність семантико-стилістичних ознак одиниці мови, які забезпечують іiі здатність виступати в комунікативному акті як засіб суб'єктивного вираження ставлення мовця до змісту чи адресата мовлення [6, с. 591]. На нашу думку, категорія суб'єктивної модальності є значно ширшим поняттям, одним із прийомів вираження якої є експресивні засоби. Услід за В. Чабаненком, «експресивний» розуміємо як «інтенсифіковано (збільшено, підсилено) виразний» [9, с. 7].

До синтаксичних експресивних засобів у художньому мовленні відносимо звертання, серед яких за стилістично-функціональною ознакою найчастіше виділяють власне звертання і риторичні звертання.

Власне звертання здебільшого використовуються в художніх текстах для стилізації усного мовлення в репліках герїв. Наприклад: - Вікторе, я хотіла вам зізнатися в дечому. - Будыте обережні, Антоніно Василівно, - він лукаво мружиться [7, с. 144].

Звертання найчастіше вживається в таких різновидах речень, як спонукальні i питальні, які мають прагматичну комунікативну спрямованість: спонукають співрозмовника до дії чи відповіді. У цьому найбільше проявляється стилістична зорієнтованість висловлюваного, переданого структурою спонукального чи питального речення. Наприклад: - Сідайте, Іване Степановичу. - Сердюк із значимою серйозністю вказав на крісло,сам - за стіл [3, с. 120]; - Чого тобі, синку? [3, с. 70].

Особливими експресивними центрами в художніх текстах $€$ риторичні звертання, які здебільшого мають метафоричний зміст i використовуються не для називання особи, до якої звернена мова, а є засобом виявлення почуттів, переживань. Наприклад: Ой палка ти була, моя пісне! [8, с. 99]; Країно рідная! Ох, ти далека мріс! До тебе все летять мої думки [8, с. 150].

Звертання, категорійно не змінюючи синтаксичної будови речення, надає йому експресивного забарвлення, бо частково чи суттєво змінює всю реченнєву тональність, мовленнєву орієнтацію вислову. Так, крім апелятивної функції, звертання можуть виконувати 
ще функцію кваліфікації адресата: - Спокійно, любий друже, сказав Сердюк [3, с. 172]; Ха-ха, - думає Ваня, - і там тебе дістали, жнрожопий боягуз! [7, с. 191].

Особливим синтаксичним, стилістичним різновидом звертань $€$ вокативні речення, які завжди виразно емоційні. Ці одиниці можуть виражати заклик, прохання чи вимогу відповісти, відгукнутися тощо: - Марто! Зустрінь клієн... шановного Івана Степановича! [3, с. 114].

Окремі вокативні речення виділяються яскраво вираженою емоційністю, унаслідок чого значення спонукання дещо послаблюється. Наприклад: - Куме? - прошепотів. Як заверещить: Куме! Куме Микишко! Невже ти? Пресвята Богородице небесна, $і$ Ти, святий Боже єоиний! Куме! [3, с. 7].

Відображаючи емоційно-вольову сферу мовця, звертання поєднують дві функції: апелятивну та експресивну. Апелятивна функція виявляється в офіційному спілкуванні. У художньому мовленні звертання виражає не лише звернення до адресата, а й ставлення з боку мовця до нього.

Багаті експресивні можливості мають також номінативні речення, у яких головний член виражає одночасно й образ предмета, й ідею його існування в теперішньому часі. Звідси їх лаконізм, образність, виразність. Наприклад: Оку важко знайти красу в тому гештальті. Тим більш коли ти виріс на Подолі, де золоті куполи цеерков вищі за дахи будинків. Фролівський монастир, Покровська церква, Богородиці Пирогощі, Миколи Притиска, Іллінська, Христо-Воздвиженська, дзвіниця церкви Миколи Доброго, Набережно-Микільська та Різдва Христового, де Кобзаря відспівували... А над ними - Андрї̈вська. А в повітрі - Божа благодать від передзвону [3, с. 15].

Номінативні речення створюють образні, видимі картини. Автор намічає контури картини, які читач «домальовує» відповідно до своєї творчої уяви. Такі структури використовуються для створення фону, на якому відбувається основна дія. Крім того, номінативні речення можуть передавати особливий емоційний стан героя, швидкий перебіг думок: Космос плюс дівчина - вони з Гоциком і Люба. Вишні, пиво, футбол. Че Гевара, дурні розмови і фантастичні мрії. Пішла корекція. Азарт, гордість. Вони не чіплятимуться за дрібниці! Особистості! Амбітна провінціцйна голота... [3, с. 110].

Як засіб експресивного синтаксису ми розглядаємо конструкції 3 називним уявлення - особливим різновидом односкладних номінативних речень. Ужитий у препозиції речення чи складного 
синтаксичного цілого, називний уявлення викликає в читача уявлення про реалію, якій присвячений подальший виклад думок. Речення, що йдуть за називним уявлення, тематично з ним пов'язані. Тому називні уявлення в лінгвістиці ще характеризують як називні теми, адже вони, називаючи особу або предмет, викликають у читача чи співбесідника уявлення про об’єкт, який є темою розмови. Наприклад: Київ... Ох! файну ж забаву Господь Всемогутни умислив - щуоби християнський рай на киталт Києва впорядкувати. Оче діло! Он де, ліворуч, Берестове. За ним - Печерське, Лаври... Митрополит, певно, й у раю за грішні душі молиться... А праворуч, біля Глибочиці, домівки подільських кожум'як, у яких вони з кумом Свирею одного разу таке добре пиво куитували, щуо його навіть сам гетьман хвалив. Та все веселе од вогнів. Ох! веселе [3, с. 8].

Називний уявлення вводить читача у філософські роздуми героя, у ситуацію спогадів про важливі події. Конструкції з називним уявлення надають висловленню розчленованості й водночас лаконічності, є одним із способів експресивної передачі інформації різного змісту.

Експресивністю відзначаються в текстовій канві художніх творів також неповні речення. Зауважимо, що синтаксична неповнота виявляється в компресії мовлення шляхом інтеграції вербальних i невербальних засобів при формуванні змісту повідомлення. У цьому виявляється національна специфіка структурування різних типів діалогічного й монологічного мовлення.

Найбільшою частотністю відтворення відзначаються неповні речення у структурі художнього діалогу - стилізованій моделі уснорозмовного мовлення. Наприклад:

- Рома? Моя дівчина... на моӥх очах кинулася з мосту...

- Так... Швидко звідти! Ти чув? Максе! Ти мене почув? Линяй звідти негайно! [3, с. 12].

- Марто, де Шиллер?

- Здається, на побаченні...

- Як повернеться - до мене!

- Вәсе дзвоню! - проторохтіла Марта [3, с. 127].

Неповнота речень у діалогічному мовленні зумовлюється особливою функцією породження i налагодження смислів у процесі спілкування адресанта й адресата та визначається правилами діалогового спілкування, пресупозицією комунікантів, екстралінгвістичними чинниками.

Неповні речення в поєднанні з обірваністю фрази - експресивний засіб відтворення переживань героя, гарячкованості думок в екстремальній ситуації. Наприклад: Нa місm - нікого. У воду - 
нікого... Ближче до води. А ті баби, щуо на ногах, як смиконуть. Перечепився, упав... На воду. Та що жс це?! Жарти у нас тут такі... Жарти у нас тут... Жарти, жарти... Не могла ж вона, дійсно, кинутися... У воді нікого. Щось воно... [3, с. 12]; - Ну... Добре. Давай. Ось екстазі... Проковтни... Нелогічна радість і енергія дії забезпечені. Упіймаєш кайф і... по-швидкому... [3, с. 45].

Засіб експресивного синтаксису - парцеляція. Парцеляція, за Л. І. Конюховою, - стилістичний прийом, що полягає у виокремленні висловлювання (речення) у самостійну одиницю [15, с. 33]. Інакше кажучи, явище парцеляції являє собою подачу речення у вигляді двох або кількох фраз з експресивною метою. Парцельовані конструкції властиві як на рівні простого, так і на рівні складного речення.

Речення з парцельованими присудками мають свої особливості і певні експресивні можливості. Серед парцельованих присудків, як засвідчують спостереження, найчастіше піддаються парцельованню однорідні присудки. Наприклад: У монастирській иеркві на самому переді в щапках два матроси під час служби курять цииарки. Курять $i$ просміхаються [2, с. 94]; Гнат вже один. Сидить і думає [2, с. 130].

Виокремлені однорідні присудки недоконаного виду виражають послідовні етапи одного процесу. Парцеляція тут виступає засобом семантичного підкреслення від однієї до іншої дії, надаючи висловлюванню експресивності, динамізму. Сполучник $i$, яким починається парцельована фраза, також вказує на послідовність дії. Наведений приклад свідчить, що парцеляція дає змогу реалізувати довгий структурний ланцюг, а це сприяє легшому сприйняттю контексту читачем чи слухачем, робить висловлювання чіткішими, виразнішими: друга ж фраза стає більш випуклою, помітною. Це означає, що парцеляція виконує й свою функцію експресивізації.

У ролі парцелятів можуть виступати і другорядні члени речення. Наприклад: Ніч у Миронівці однакова кожної пори року, навіть у травні. Така жс темна й одинока [7, с. 240]; Дівчина припала до мостової огорожі: видивляється щуось на печерських схилах, видивляється... Усміхається, сухі губи облизує. Плечиком смикнула усі геть! Невразлива, нездоланна, безсмертна $[3, \quad$ с. 6]; Повантажували вози різним майном, свати шугали потай по домашиному господарстві $і$ щуо могли похопити, перли і пакували на підводи. Кури, гуси, якісь коноплі, стару ступу [2, с. 35]; $A$ скрізь повно чужих людей. І на лавах, $і$ за столом, і в зачіпку [2, с. 10].

Парцеляція підвищує експресивну наголошеність кожного елемента висловлювання, підсилює напруженість думки, сприяє 
створенню своєрідної ритмомелодики тексту. Така форма побудови синтаксичних конструкцій допомагає глибше зрозуміти зміст, дає змогу автору висловити своє ставлення до зображуваного, а читачеві краще зрозуміти авторську оцінку.

Парцеляти, неповні, а також обірвані речення досить часто складають основу невласне прямої мови - потужного засобу експресивності, за допомогою якої відтворюється дійсність у різноманітних суб' єктних зображеннях.

Найхарактерніший модальний тип невласне прямої мови форма питальних та вигукових речень, що виділяються в емоційному та інтонаційному плані на тлі авторської оповіді. Наприклад: Повернулася в дім, притиснулась спиною до дверей. Льончик ще плаче? Зараз минеться... Усе по-новому тепер, усе не так, як було... Щоб одразу, безповоротно - і жодного сліду! [2, с. 153].

Експресивність посилюється, якщо кілька питань у складі невласне прямої мови об'єднуються в структурно-смислову єдність, внаслідок чого створюється особлива стилістична фігура ампліфікаія. Наприклад: Голова обертом. Погнав до иентру... Холодний розум, як майстерний фотограф, підкинув об 'єктивні кадри минулої ночі, залишивии простір істеричним емоціям. I що тепер? Що тепер? Як він без неї?.. І вже не «чому?», а «за щио?» [3, с. 142]. Ампліфікація питальних речень створює емфатично інтонований, почуттєво напружений темантичний комплекс вислову. Загалом же невласне пряма мова відтворює психічний процес у його динаміці, дає змогу авторові суб'єктивний світ героїв органічно ввести у свою оповідь. Створюється двоплановість висловлення: передається внутрішнє мовлення персонажа, його думки, настрої, але виступає за нього автор, оцінка подій письменником перетинається зі сприйняттям художньої дійсності персонажем. Таким чином розширюється суб'єктно-експресивна багатоплановість оповіді, окреслюється образ автора і образи персонажів.

Отже, засоби експресивного синтаксису сприяють смисловій конденсації й логічному увиразненню думки, розставляють акценти на важливих елементах художнього тексту, увиразнюють експліцитно виражений зміст і розкривають глибинні смисли, породжують певний тон мовлення, завдяки чому допомагають емоційно вплинути на читача.

\section{Література}

1. Балли Ш. Общая лингвистика и вопросы французского языка / Ш. Балли. - М. : Изд-во иностр. лит., 1955. -416 с.

2. Бедзик Ю. Чорний лабіринт / Ю. Бедзик. - К. : Воєнвидав, 1991. - 319 с.

๑ Т. І. Вавринюк, 2013. 
3. Дашвар Люко. РАЙ. Центр / Люко Дашвар. - Х. : Клуб Сімейного Дозвілля, 2010. $-272 \mathrm{c}$.

4. Загнітко А. П. Теоретична граматика української мови : Синтаксис : [монографія] / А. П. Загнітко. - Донецьк : ДонНу, 2001. - 662 с.

5. Конюхова Л. І. Явище парцеляції в мові сучасних засобів масової комунікації : автореф. дис. ... канд. філол. наук / Л. І. Конюхова. - Л., 1999. - 15 с.

6. Лингвистический энциклопедический словарь [гл. ред. В. Н. Ярцева]. - М. : Советская энциклопедия, 1990. - 685с.

7. Малярчук Т. Звірослов / Т. Малярчук. - Х. : Фоліо, 2009. - 281 с.

8. Чабаненко В. А. Стилістика експресивних засобів української мови : [монографія] / В. А. Чабаненко. - Запоріжжя : ЗДУ, 2002. - 351 с.

Стаття надійшла до редакції 19.11.2013 р. 